\title{
Status of Fish Farming in Makueni County, Kenya
}

\author{
Maina, J. G. ${ }^{1}$, Wesonga, P. S. ${ }^{2, *}$, Mukoya-Wangia, S. ${ }^{3}$, Njoka, J. T. ${ }^{4}$ \\ ${ }^{1}$ Department of Animal Production, College of Agriculture and Veterinary Sciences, University of Nairobi, Kenya \\ ${ }^{2}$ Department of Land Resource Management and Agricultural Technology, College of Agriculture and Veterinary Sciences, University of \\ Nairobi, Kenya \\ ${ }^{3}$ Department of Agricultural Economics, College of Agriculture and Veterinary Sciences, University of Nairobi, Kenya \\ ${ }^{4}$ African Drylands Institute of Sustainability, College of Agriculture and Veterinary Sciences, University of Nairobi, Kenya
}

Copyright $\bigcirc 2017$ by authors, all rights reserved. Authors agree that this article remains permanently open access under the terms of the Creative Commons Attribution License 4.0 International License

\begin{abstract}
This study assessed the status of fish farming in Makueni County, Kenya in 2015 (three years after expiry of Economic Stimulus Programme (ESP). The study sampled 146 fish farmers. Based on the study results, Makueni has a vibrant fish farming activities along rivers Athi, Makindu and Kiboko with $46.6 \%$ active fish farmers. Females consisted 43.2 of fish farmers, a good indication in alleviating poverty and food insecurity. Ninety four percent of farmers practice tilapia (Oreochromis niloticus) monoculture on a semi intensive system. A situational analysis using Strengths, Weakness, Opportunities, Threats (SWOT) identified: Main strengths were catfish (Clarias gariepinus) potential as first choice of fish production, excellent extension-farmer contact links, and private hatchery development. Opportunities that can be promoted include public-private collaboration in infrastructure development, extension, wildlife conflict and research among others. The study recommended that Fish farmers, County officials and National policy makers concentrate on identified SWOT in order to collaboratively develop a sustainable fish-farming sector. Secondly, County government should identify serious fish farmers and increase its collaboration programs that promote suitable pond selection sites, quality affordable feeds, postharvest refrigerated cooling systems and hatchery development. Academic significance of the study is that fish farming can be sustainable practiced in Arid and Semi-arid Lands (ASALs) if there is a collaborative efforts between farmers and the public sector.
\end{abstract}

Keywords ASALS, Catfish, ESP, Food Insecurity, Poverty, Tilapia

\section{Introduction}

The Kenya national government under its Vision 2030 between 2009 and 2012 [1] identified fish farming as an alternative livelihood strategy for communities in Arid and Semi-Arid Lands (ASALs). Aquaculture is a recent enterprise in Makueni County encouraged by the government beginning in the 1990s and reinforced during the 2009-2012 Economic Stimulus Programme (ESP) as documented by Makueni County Fisheries Department (MCFD)[2]. The ESP to promote fish farming in Makueni was implemented in 2009-2012 under the leadership/stewardship of the Fishery department. Prior to 2009 it is estimated that Makueni had less than 100 fish farmers [3]. These farmers had smaller ponds in their homestead and along the permanent river basins. The key farming enterprises in Kibwezi were horticulture, livestock, poultry, sand/quarry mining and subsistence farming of cereal crops like maize and beans [4].

The main types of fish farmed are tilapia (Oreochromis niloticus and catfish(Clarias gariepinus) under a semi intensive system [5]. Makueni county has six constituencies and four of them were assigned a quote of 300 each with the rest 100 a piece [6]. Kibwezi had 316 registered fish farmers in the Fisheries record [7]. Global Position System measurements showed that the fish ponds were located between 697.3 and 1222.7 Metres above sea]. Level [8]. Kenya's annual aquaculture production exceeded 12,000 Metric tonnes (Mt) in 2010 [4b]. The former Ministry of Fisheries Development (MOFD) classified the 12,153Mt of harvested farmed fish into: Nile tilapia 9,115Mt, African catfish 2,118Mt and carp 729Mt. These were harvested from 23,478 ESP ponds and 8,399 Non ESP ponds [9]. By 2013, according to the Kenya National Bureau on the Statistics, Kenya's total fish production was 152,711 , tonnes of which 23,501 tonnes came from aquaculture [10] as a result of adopters of the concluded ESP in 2012.

\section{Materials methods}

\subsection{Study Area}

The study area was Kibwezi that now consists of Kibwezi East and Kibwezi West (Makindu) Sub-Counties of Makueni as shown in Figure 1. 


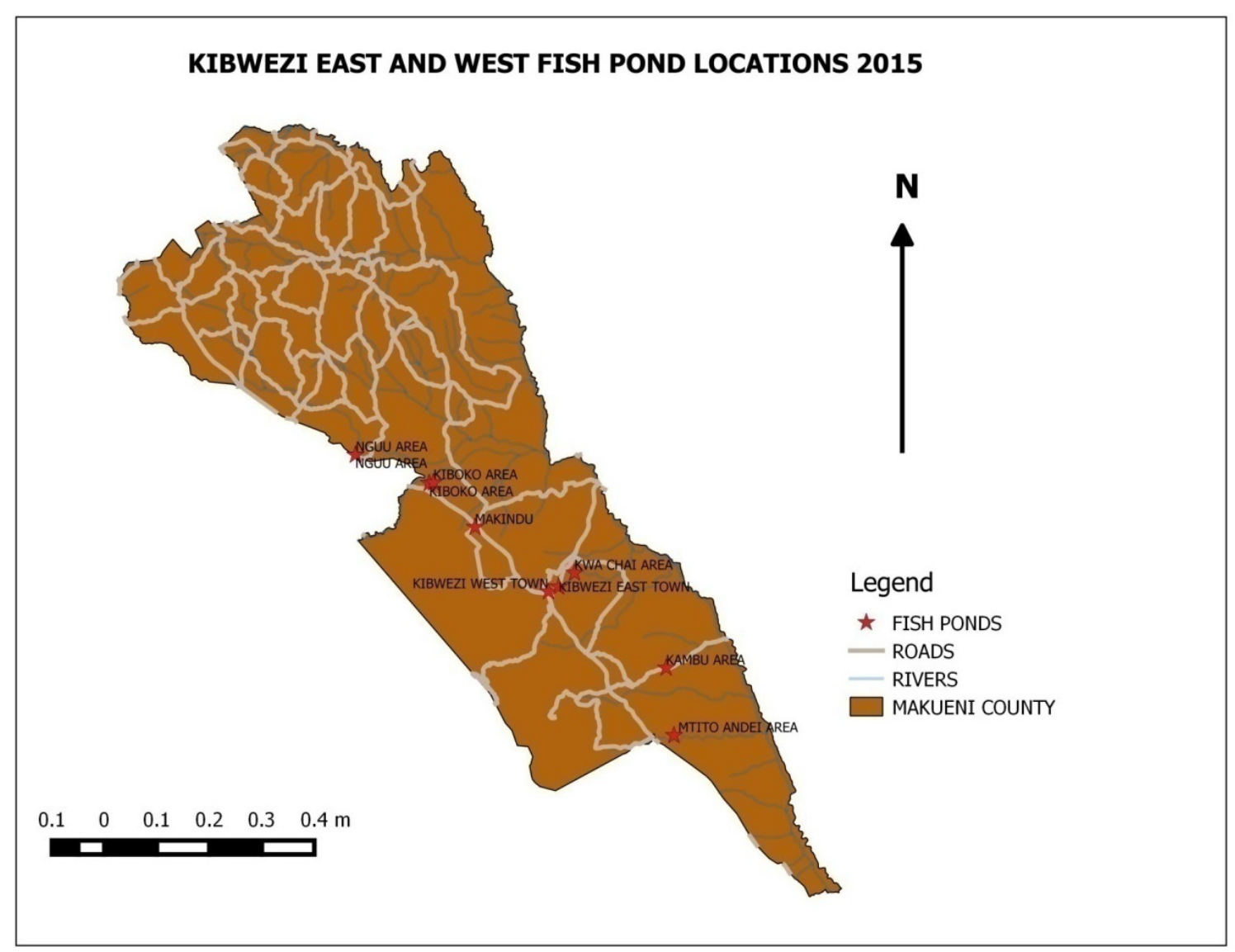

Source: GPS field survey, 2015

Figure 1. Study Site: Makueni( Mtito Andei to Nguu Corridor)

The study area was chosen by researcher because of two reasons; first, Kibwezi has highest concentration of fish farmers in Makueni County. Secondly, there was need to gain knowledge that can be used to enhances fish farming in ASALs of Kenya.

\subsection{Research Design/Sampling Framework}

There are two prototypes of conducting research: phenomenological and positivist approach as defined by Cooper [11]. A phenomenological approach uses certain universal patterns to settle on a conclusion while positive approach involves use of quantitative analysis to derive conclusions. A positive approach was used to arrive at conclusions that dealt with quantitative data while a phenomenological approach was used to make conclusion on qualitative questions encountered in this study.

To establish status of fish farming, the Researcher visited with County Agricultural, livestock and Fishery Department [12] official in both Wote and Kibwezi. These officials supplied Researcher with secondary data on registered fish farmers and related support programs. The records showed that a total of 1225 fish farmers were registered in Makueni County, of which 316 were in Kibwezi. An initial survey was done that mapped out the county to establish status of fish farming. This involved purposive sampling of Key Informants (KI) that were interviewed or participated in focus group discussions (FGD). Other primary data came from field survey of 146 sampled fish farmers

\subsection{Data Collection}

Gathering of primary data sources relied on quantitative methods and use of questionnaires or guide. Key Informant questionnaire and FGD guide were reviewed by an aquaculture and Extension Specialists (August, 2014), while that of fish farmers was pre-tested on 10 randomly selected fish farmers in Busia County (January 2015). Amendments were made on the questionnaires as per above stakeholders' suggestions and comments. These questionnaires were then printed and used in field. Data was collected in two phases a preliminary inquiry (September 9- 12,2014) followed by a fish farmers survey in Kibwezi (February and March, 2015).To establish a start point and we used both secondary data at close of August 31, 2014 and primary data from Key Informants (KIs) as noted below. Using purposive sampling, 18 key informants were interviewed and two focus group discussions done. Key Informant questionnaire (Appendix 1) was used to interview Key informants and FGD guide (appendix 2) to facilitate discussion. Focus group discussions were divided into two groups: County agriculture officials and selected Kibwezi fish farmers. The county agricultural officials FGD was done at Wote on September 11, 2014, while that of selected Kibwezi fish 
Farmers was done at Makindu on September 12, 2014. Socio-economic, management practices and marketing information were derived from fish farmers' questionnaire done between February and March, 2015.

\subsection{Data Analysis}

The collected data were entered into a spreadsheet and analyzed using Statistical Package for Social Science (SPSS 22). The data were then subjected to a descriptive statistical analysis. Information on fish farmers' social and economic status was summarized in terms of central tendencies, frequency table and cross tabulations.

A situational analysis of fish farming was done using Strengths, Weaknesses, Opportunities and Threats (SWOT) to determine way forward. SWOT assessed fish farmers challenges vies government contribution to fish farming as an alternative likelihood strategy in ASALs.

\section{Results and Discussion}

\subsection{Overview of Fish Farming}

Based on the Key Informants interview with the County fishery official in September, 2014, the registered fish farmers were 1300 during the ESP subsidized period 2009-2012. Out of 1300 farmers, 1225 started fish farming through ESP incentives spread between 2009 and 2012. It can be concluded that 75 fish farmers had been in fish farming prior to the introduction of Fish Farming Enterprise and Production Programme. After the subsidy period, the current county fish farming position includes 23 public dams stocked by the Fisheries Department and 850 fish farmers [13]. Most of those fish farmers are concentrated in Kibwezi, which has 192. Most of the fish ponds constructed in Kibwezi are constructed using earth as in Table 1 mainly along the river banks of Athi, Makindu and Kibwezi; Liner and concrete ponds mainly at institutions and farmers' home; large earth dams in Mbooni and Sand dams [13].

A majority $58.9 \%$ of the fish ponds were earthen as in Table 1 which is consistent with other studies finding by Munguti et al. [14], Mucai et al. [15] and Ngugi et al. [16]. Earthen ponds are favored option by farmers in Africa because of its affordability in construction as compared to Concrete and liner ponds.

Table 1. Types of fishponds constructed by farmers in Kibwezi

\begin{tabular}{cccc}
\hline Variable & Category & Frequency $(\mathbf{n = 1 4 6})$ & Percent \\
\hline \multirow{3}{*}{$\begin{array}{c}\text { Type of pond } \\
\text { used }\end{array}$} & Earth & 86 & 58.9 \\
& Liner & 50 & 34.2 \\
& Concrete & 10 & 6.8 \\
& Total & 146 & 100 \\
\hline
\end{tabular}

Source: Authors, (2015)

From Table 2 it is observed that only $2.1 \%$ of the fish ponds had been built before 2009, however with the ESP promotion the number shot up by 93.1 percent. However this increase has not translated into more farmers converting into fish farming as it can be noted from the same Table that by 2015 only $46.6 \%$ of farmers were actively engaged in fish farming. Over $47.9 \%$ had abandoned their fishpond. These findings are consistent with those of Howard [17] who observed that 41 percent of fishponds in Kisii were abandoned.

Table 2. Year fishpond built and fish farmer status

\begin{tabular}{cccc}
\hline & & Frequency & Percent \\
\hline \multirow{3}{*}{$\begin{array}{c}\text { Year pond } \\
\text { built }\end{array}$} & Before 2009 & 3 & 2.1 \\
& After 2012 & 136 & 93.1 \\
& Total & 7 & 4.8 \\
& Active & 68 & 100 \\
Fish Farmer & Inactive & 10 & 46.6 \\
status & Abundant & 70 & 5.7 \\
& Total & 146 & 47.9 \\
& & & 100 \\
\hline
\end{tabular}

Source: Authors, (2015)

Results of the study found that Makueni county has seven private hatcheries with four of those located in Kibwezi, Mbenzei and Gikonyos' located in Kibwezi Town; Wethe Farm-Kiboko; Candy farm-Kiboko). These hatcheries have one major challenge that of substandard methods of fingerling producing. Two of those hatchery owners are revamping and updating their operations to mitigate the challenge. The County does not have a public operated hatchery. The study area has experienced a $57 \%$ a dropout. Based on the above discussion, it is apparent that fish farming has not attained its expected rate of adoption in the county.

Fish fingerlings was sourced from local private hatcheries $34.3 \%$ that specialized in catfish and tilapia, while $52.1 \%$ of the farmers bought their fingerlings from Machakos, Kitui, Sagana, Kibos, and Nairobi see Table 3. This made fingerling less accessibility and costly to farmers. This agrees with Adewuyi et al. [18] study in Nigeria who found that it not securing fingerlings locally increased the cost of their procurement.

Table 3. Source of fingerlings

\begin{tabular}{ccc}
\hline Fingerling & Category $\mathrm{n}=146$ & Percent \\
\hline \multirow{3}{*}{ Source } & Local & 34.3 \\
& Out of county & 52.1 \\
& Others & 13.7 \\
& Total & 100 \\
\hline
\end{tabular}

Source: Authors, (2015)

The findings in Table 4 show that 71 percent of fish farmers are within the age bracket of 30-59 years. These findings collaborate studies done by Okechi [19], and Maina et al. [20] in Kenya; Olowoegun et al.[21], Olaoye et al. [22] 
and Osondu [23] in studies done in Nigeria that found a positive correlation between age and adoption of fish farming technologies for farmers below 50 years. Fish farming requires a lot of hard work and financial resources to cover the variable costs (feeds, Labour etc.). The youthful age provides the manpower of operating a fishpond while mid age farmers have the financial resources saved from their primary likelihood that could be invested into fish farming.

Table 4. Socio-Economic Factors

\begin{tabular}{|c|c|c|}
\hline Variable & Category in years & Percentage \\
\hline \multirow{6}{*}{ Age $n=146$} & $18-19$ & 2.7 \\
\hline & $20-29$ & 13 \\
\hline & $30-39$ & 24.7 \\
\hline & $40-49$ & 26 \\
\hline & $50-59$ & 24 \\
\hline & Over 60 & 9.6 \\
\hline \multirow{2}{*}{ Gender $n=146$} & Male & 58.9 \\
\hline & Female & 41.1 \\
\hline \multirow{3}{*}{$\begin{array}{c}\text { Marital Status } \\
n=146\end{array}$} & Married & 80.8 \\
\hline & Single & 13.0 \\
\hline & Other & 6.2 \\
\hline \multirow{5}{*}{$\begin{array}{c}\text { Education Level } \\
n=146\end{array}$} & Primary & 30.2 \\
\hline & Post primary vocation & 8.2 \\
\hline & Secondary/A- Level & 30.1 \\
\hline & Tertiary College & 21.1 \\
\hline & University & 10.3 \\
\hline \multirow{5}{*}{$\begin{array}{c}\text { Main livelihood } \\
n=146\end{array}$} & Subsistence farmer & 7.6 \\
\hline & Employ-salary & 36.2 \\
\hline & Business & 34.8 \\
\hline & Informal employment & 16.3 \\
\hline & Other & 5.1 \\
\hline
\end{tabular}

Source: Authors (2015)

Females represented 41 percent of fish farmers in the study area. These results are inconsistent with most studies that show fish farming to be predominantly male. In Adewuyi et al. [24] study in Ogun State of Nigeria where $87.7 \%$ were male vis $12.3 \%$ female. Other studies done in Kenya by FAO[23] in Western Kenya and Njagi et al. [25] in Meru, Kenya that found males were disproportionately represented as fishpond owners. In Ghana, Asmah [26] found out that only $5 \%$ of fishponds were owned by female against $95 \%$ owned by males. The high representation of women fish farmers in Kibwezi mirrors findings by Mutambuki et al. [27] where 31 percent of fish farmers were female in a study done in Kitui, an area with almost similar socio-economic and ecological characteristics. The Kibwezi study is a significant contribution to aquaculture because it points to an area that could be used as a model of promoting gender parity in fish farming in ASALs. Secondly, when ownership of key protein sources is by a mother, there is a high probability that household members will be fed appropriately.
Over 58.4 percent of fish farmer had attained at least secondary level as shown in Table 4. These educational levels are consistent with studies done in Western Kenya by FAO [28] where farmers with over 12 years of education had a positive influence on fish farming. In Kibwezi more years of education should increase the adoption rate of fish farming.

These results contrast with studies done by Asmah [25] in Ghana and Njagi et al. [27] in Meru, Kenya that found 44 and 56 percent of fish farmers respectively had only primary education.. In Ghana, fish farmers had been fish rearing for ten years. Thus lower levels of education are compensated by longer years of farming experiences in the adoption of fish farming.

\subsection{County Infrastructure Support for Fish Farmers}

The county does not have a public hatchery or a feed pellet plant noted from the key informants results. The implication of this is that quality of fingerlings delivered to Kibwezi farmers cannot be guaranteed. Poor quality fingerlings means average weight of fish harvested is low which affects gross margins negatively. With no local feed pellet plant, fish feeds will continue to be unaffordable to farmers. When feeds are not affordable it increase the probability of farmers not feeding the fish. The county does not plan to build a hatchery or feed pellet factory, however county officials are working with farmers to establish a cooling and refrigeration centre to assist farmers with postharvest storage.

\subsection{Management Practices}

The farming practice is polyculture in the large earth dams that are restocked with Nile tilapia and African catfish by the County Fisheries Department. The large earth dams are managed by local communities or fish farmer groups. A majority of fish farmers use fishpond size of $300 \mathrm{M}^{2}$. Monoculture is practiced with nile tilapia preferred over catfish. The weight range of mixed tilapia is $150-310$ grams. County extension officials have been encouraging farmers to shift from mixed tilapia farming to mono-sex male tilapia farming that weighs between 350-500grams after six months of growth [26].

The main sources of water for farmers were permanent rivers at $45.6 \%$ followed by public piped water at 31.5 as showed in Table 5. Rainwater is not a common option of filling fishponds although this has captured significant amounts of water to complement most used sources of water.

The primary water used was pumped from the following sources as in Table 5. Gravity flow is rarely practiced.

Table 5. Sources of water

\begin{tabular}{ccc}
\hline Source of water & Frequency $\mathrm{n}=146$ & Percent \\
\hline Permanent river & 67 & 45.9 \\
Well or borehole & 30 & 20.5 \\
Public piped & 46 & 31.5 \\
Seasonal & 3 & 2.1 \\
\hline
\end{tabular}

Source: Authors, (2015). 
Table 6 shows the type of fish farming system practiced in Kibwezi. Most farmers are using semi-intensive system as the dominant mode of production. Of significant is the $8.9 \%$ farmers who are using the integrated system, this system allows the farmer to fully utilize their resources from other enterprises.

Table 6. Type of production system and fish culture

\begin{tabular}{ccc}
\hline Fish farming system & Frequency $\mathrm{n}=146$ & Percent \\
\hline Extensive & 11 & 7.5 \\
Semi-intensive & 122 & 83.6 \\
Integrated & 13 & 8.9 \\
Fish culture & Frequency $\mathrm{n}=146$ & Percent \\
Tilapia & 138 & $94 . .5$ \\
Catfish & 8 & 5.5 \\
\hline
\end{tabular}

Source: Authors, (2015)

Tilapia and catfish are the two fish type reared as shown in Table 6. This result is consistent with Maina [13] study in Kirinyaga County.

\subsection{Production and Marketing}

Farmers normally weigh their fish by estimation and then sell them by the piece. Samples of fish sold at KES 80.00 and KES 100.00 were weighed to get a representative average weight of 200grams and 250grams respectively.. The result show that average price per Kilogram was KES 400.00 (US\$4.00) of fresh tilapia or catfish. Farmers normally sell 200 grams fish for KES 80.00 and KES 100 for a 250grams fish. The average harvested tilapia is 240 grams. A majority of harvested fish is sold at farm gate and local markets as in Table 7

Table 7. Distribution of fish farmers based on point of sale

\begin{tabular}{ccc}
\hline Final fish markets & Frequency $(\mathrm{n}=146)$ & Percent \\
\hline Local & 134 & 91.8 \\
Regional & 12 & 8.2 \\
\hline
\end{tabular}

Source Authors, (2015)

The above scenario could be a due to minimum processing of the fish and limited cold postharvest storage facilitates that hinders farmers from seeking lucrative regional markets. There is very limited fish promotion by the farmer especially at the farm gate and local markets. Farmers that sell in distant markets of Voi and Gikombe, Nairobi do discount promotion based on bulk purchases of the buyer. Bulky buyers at the farm gate are normally brokers and fish hawkers. Brokers transport their fish to Voi, Nairobi or Mombasa for final sale. The fish hawkers sell to final consumers in the local markets. The fish hawkers can sell fish in its fresh or deep fried form. The Majority of fish harvested in Kibwezi is done in July-September and December-January, thus there is no steady supply during the year.

Kibwezi fish farmers are concentrated along the Email MtitoAndei corridor situated on main Nairobi to Mombasa paved roads. Also Makindu to Wote has paved road, thus key fish markets like Wote, Machakos, Nairobi, Voi and Mombasa can be easily accessed to sale fish harvested.

There is minimum processing of the fish that is sold locally.

\subsection{Strengths, Weaknesses, Opportunities, Threats (SWOT)}

Based on the above descriptive statistics, the following variables fingerling, feeds, labor, water, pond size, funds, infrastructure and extension were taken as a whole to derive the SWOT analysis in Table 8

Table 8. SWOT analysis of fish farming in Makueni, Kenya

\begin{tabular}{|c|c|}
\hline & SWOT \\
\hline \multicolumn{2}{|l|}{ Strengths } \\
\hline 1. & More earth pond development in black clay soils \\
\hline 2. & $\begin{array}{l}\text { Fish farming is environmentally friendly since water waste } \\
\text { is used on agricultural farms }\end{array}$ \\
\hline 3. & $\begin{array}{l}\text { County support in promoting fish farming through } \\
\text { extension services, farmer in service training and grants. }\end{array}$ \\
\hline 4. & $\begin{array}{l}\text { Development of unused credit access in improving fish } \\
\text { farming }\end{array}$ \\
\hline 5. & Catfish potential as a fish of choice in fish production. \\
\hline \multicolumn{2}{|c|}{ Weaknesses } \\
\hline 1. & Poor selection of fish pond sites \\
\hline 2. & Inappropriate technologies \\
\hline 3. & Poor socio-economic status of fish farmers \\
\hline 4. & $\begin{array}{l}\text { Limited funds and use of credit facilities for fish farmer and } \\
\text { extension services }\end{array}$ \\
\hline 5. & $\begin{array}{l}\text { Overreliance on public agencies to provide key input } \\
\text { supplies (fingerling, and feeds) }\end{array}$ \\
\hline 6. & $\begin{array}{l}\text { Conflict between fish farmers and other users (agricultural } \\
\text { (crop/livestock human consumer and Industrial) }\end{array}$ \\
\hline \multicolumn{2}{|c|}{ Opportunities } \\
\hline 1. & $\begin{array}{l}\text { Great potential for fish farming growth along permanent } \\
\text { river basin }\end{array}$ \\
\hline 2. & $\begin{array}{l}\text { Adequate supervision and monitoring potential : high } \\
\text { extension visit with fish farmers }\end{array}$ \\
\hline 3. & $\begin{array}{l}\text { Potential for strategic public-partnership like hatchery } \\
\text { development/ home feed development and collaborative } \\
\text { research }\end{array}$ \\
\hline 4. & $\begin{array}{l}\text { Collaboration with Kenya Wildlife Services to reduce } \\
\text { human-wildlife conflict }\end{array}$ \\
\hline \multicolumn{2}{|l|}{ Threats } \\
\hline 1. & $\begin{array}{l}\text { Insufficient participation in planning, implementation and } \\
\text { evaluation of fish farmers' programmes with other } \\
\text { stakeholders-government }\end{array}$ \\
\hline 2. & $\begin{array}{l}\text { Inadequate and untimely release of county budget and } \\
\text { grants for fish farming promotion }\end{array}$ \\
\hline 3. & $\begin{array}{l}\text { None dynamic responses to farmers' challenges- seed/feed } \\
\text { quality, Water availability, liner costs }\end{array}$ \\
\hline 4. & Unstable government policy \\
\hline 5. & $\begin{array}{l}\text { Weak professional and institutional linkage among fish } \\
\text { farmers, research and extension }\end{array}$ \\
\hline
\end{tabular}

Source: Authors, (2015)

Ronnbeck [29] in a study done on the Kenyan Coast found out that fish farming requires a lot of trust and coordination so that small-scale producers can realize its benefits. Farmers might have not had significant benefits in the form of better yields and revenues. This might have also contributed to the 
high dropout since majorities were not financially prepared to meet fish rearing costs. Secondly, original selection of sites was manipulated as some sites were not suitable for fish production as evident in the FGD and KI interviews [30].

\subsection{Challenges Faced by Fisheries Extension Officers}

The study interviewed two fisheries extension officers based in Kibwezi on challenges constraining their service delivery. The main one was not having been trained in aquaculture. This has been overcome by in-service training in fishery development, extension and husbandry practices.

This number of extension officers is sufficient for Kibwezi. Kibwezi had 316 registered fish farmers and these are clustered in key zones of the study area as shown in Figure 1. From the study, it was found that fish farmers had at least three extension contacts during a rearing cycle (eight months). The number of visits is good given the scarce public resources. However, farmers noted that extension officers were not equipped in improving quality of fingerling sourced and training them to make affordable quality feeds. This challenged could be solved by use of specialists during farm demonstration in the area or the county can collaborate with private hatchery owners to improve fingerling quality. Makueni county has continued to train them and further allowed able officers to pursue university bachelors' education to enhance their knowledge and dissemination skills to farmers

\subsection{Sustainability of Fish Farming}

The sustainability of fish farming in Makueni is promising for farmers that use earth ponds than liner ponds. This conclusion is based on the study results; Makueni had $46.6 \%$ active fish farmers and $53.6 \%$ abundant/inactive farmers. Farmers in Kibwezi have embraced fish production as a form of income generating enterprise and on average $4.8 \%$ new farmers continue to construct new fishponds per year since 2013[31]. Farmers with liner pond were 90 percent of the abundant/inactive farmers. A majority of the ponds were built between 2009 and 2012 as noted in Table 2 above. A majority of farmers practiced tilapia monoculture on a semi intensive system. However, there is need to popularize catfish production in the area given its adaptability and fast growth. A situational analysis-using SWOT identified: Main strengths were catfish potential as first choice of fish production, excellent extension-farmer contact links, and private hatchery development. Weaknesses identified poor selection of fishpond sites, inappropriate technology and poor socio-economic status of fish farmers. Opportunities that can be promoted include public-private collaboration in infrastructure development, extension, wildlife conflict and research among others. Key threats were inadequate fishery budget; unstable government policy; and overreliance on government.

There is great potential for fish farming growth along they permanent river basin which can be done by encouraging farmers to build more earth ponds. Earth ponds are cheaper to construct and maintain than liner or concrete ponds. The feeding schedule is not strictly followed due to limited cash resources to buy the feeds. Currently farmers are not utilizing credit loans to mitigate their low savings. Expensive feed cost and shortages of labor personnel have negatively affected total fish production. In adequate feeding leads to fish underweight while, limited personnel to patrol the fish pond increases the predation rate by the predators. Farmers with liner ponds have had a high fail rate which could be attributed to poor quality liners, high liner replacement cost, and most of those ponds are located in areas that are not viable for fish farming.

The county extension officers are adequate to service the farmers. But there is need to source breeding specialists to assist in producing high quality fingerlings by working with the local hatchery owners. Wildlife animals are a major threat to the development of aquaculture as was noted by farmers whose ponds were destroyed by elephants.

The collaboration among the fish stakeholders is not coordinated and there is need to strategize the working relationship.

\section{Conclusions and Recommendations}

There is high potential for fish farming especially using earth ponds farming along the permanent rivers of Kiboko, Makindu and Athi. The future for farmers with liners is poor given that a majority of in-active/abundant farmers had liner problems. On a marketing infrastructure especially post-harvest handling of fish, cooling and refrigeration systems should be business driven. The transportation system along the fish production corridor is well served by Nairobi-Mombasa and Makindu-Wote -Machakos paved roads and the upcoming standard railway gauge.

Makueni county needs to develop a hatchery that could provide farmers with high quality fingerlings. Alternatively, the county could partner with current private hatchery owners to upgrade the existing facilities to standard. Farmers should organize themselves to install the feed pellet plant given to them by the government. Home- made feed is quite appealing to farmers, however the quality of that feed is not guaranteed.

\section{Acknowledgements}

Special thanks to the Partnership for enhanced engagement in Research (PEER) Science program; Serina; Breann; Stuart; Byron; Lillian Lutsili and Rita Waudo for their financial support. We sincerely thank University of Nairobi, Ministry of fisheries especially Honourable Ruth Kyatha and her staff; Engineer Nicholas Serykhan; Jeff Miruka; Nelly Tanyai; Joshua Ng'ombe; Philip Wangia; Benson Mwengi and Jackson Muchiri for their logistic and technical support during the field survey in Makueni county. 
We are grateful to Prof. Edward Karuri; Prof. J. Imungi; and the two anonymous reviewers for their valuable contributions that improved this manuscript.

\section{Appendix 1: Key Informants (KI) Guide}

Name of interviewer.

Name of the respondent

Title.

Gender.

Socio economic characteristics of the respondent

\begin{tabular}{|c|c|c|}
\hline Gender & Age in years & Education \\
\hline & & \\
\hline Farming experience & Aquaculture training & Extension \\
\hline & & \\
\hline
\end{tabular}

Overview of Fish Farming

1. How many registered fishponds under Economic stimulus programme (ESP) are in the county? Give breakdown by ward or sub-county if possible.

2. Are there farmers who were recruited by the ESP program, but have abandoned their ponds?

3. If the answer to 2 above is yes, approximately what percentage of farmers have abandoned their fishponds?

4. What species of fish are grown?

5. How many registered/practicing fish farmers are there in this county

6. Are farmers organized into groups?

7. From where do farmers purchase fish fingerlings?

8. Approximately how many farmer groups do fish farming?

County Infrastructure Support for Fish Farming

9. Has ministry built a cold storage facilities or processing plant for fish in the county?.

10. How much money does the county plan or spend in promoting fish farming in the County.

11. Does the County have a fish hatchery?

If yes where.

12. If no to question 11 does the county plan to establish one?

Management Practices

13. How are the fishponds constructed? Concrete....... Earth...... Liner.......

14. Fish farming practices: Monoculture......... Polyculture

15. What species of fish are grown?

Marketing

16. Where do farmers sell their fish and average price per kilogram?

Challenges

17. What are the main challenges faced by fish farmers?

18. Are there challenges in obtaining the fingerlings?

\section{Appendix 2: Focus Group Discussion (FGD) Guide}

Name of Facilitator.

Venue.

Date.

Overview of Fish Farming

1. Are there farmers who were recruited by the Economic Stimulus Programme (ESP) program, but have abandoned their ponds?

2. If the answer to 2 above is yes, approximately what percentage of farmers have abandoned their fishponds?

3. What species of fish are grown?

4. Are farmers organized into groups?

5. From where do farmers purchase fish fingerlings?

6. Approximately how many farmer groups do fish farming?

County Infrastructure Support for Fish Farming

7. Does the County have a fish hatchery?

If yes where.

8. If no to question 7 does the County plan to establish one?

Management Practices

9. How are the fishponds constructed? Concrete....... Earth...... Liner.......

10. Fish farming practices: Monoculture......... Polyculture

11. What species of fish are grown?

Marketing \& Extension

12. Where do farmers sell their fish and average price per kilogram?

Challenges

13. What are the main challenges faced by fish farmers/fisheries officials?

14. Are there challenges in obtaining the fingerlings?

\section{REFERENCES}

[1] GoK (2009), ESP. Overcoming Today's Challenges for a Better Tomarrow. Government of Kenya GOK. 64pp

[2] MCFD (2013), Makueni County Fishery Department, Wote, Kenya.

[3] MCFD (2013) Makueni County Fisheries Department. Wote, Kenya

[4] MCFD (2014) Makueni County Fisheries Department. Wote, Kenya 
[5] MCFD (2014) Makueni County Fisheries Department. Wote, Kenya

[6] MOF (2009), ESP. Overcoming Today's Challenges for a Better Tomorrow. Ministry of Finance, Government of Kenya. GoK. 64pp

[7] MCALF (2014), Makueni County Agriculture, Livestock and Fisheries, Wote, Kenya

[8] Authors (2015) Field survey

[9] FAO (2010) FAO Statistical Yearbook 2009 - Agricultural Production, Food and Agriculture Organization of the United Nations, Rome, Italy

[10] MOFD (2010). Ministry of Fisheries and Development, Nairobi Kenya

[11] KNBS (2014) Annual National Statistics: Kenya National Bureau of Statistics. Nairobi. Government Printer, Kenya.

[12] Cooper D.R. \& Schindler P. M. (2006) Business Research Methods (8th Ed.). New Delhi: McGraw-Hill.

[13] MCALF (2014), Makueni County Agriculture, Livestock and Fisheries, Wote Kenya

[14] Ataga R. (2014) Makueni County Ministry of Agriculture, Livestock, Fisheries, Wote, Kenya

[15] Munguti, J. and Charo-Karisa H. (2011). Fish Feeds and Aquaculture Development in Kenya. In: Samaki News: Aquaculture development in Kenya towards food security, poverty alleviation and wealth creation. Vol. 7. No. 1. pp. 27-29.

[16] Mucai, M, Wangila, B.C. and Norman N. (2011).Factors Determining Structure and Development of Fish Farming among Small Scale Operators in Western Kenya. In: Samaki News: Aquaculture Development in Kenya towards Food Security, Poverty Alleviation and Wealth Creation. Vol. 7. No. 1. pp. $30-45$

[17] Ngugi, C. C., Bowman, J. R. and Omolo, B. O. (2007).A New Guide to Fish Farming in Kenya. Aquaculture Collaborative Research Support Program, Nairobi, Kenya.

[18] Howard A.F.V., and Omlin F. X (2007) Abandoning small-scale fish farming in western Kenya leadsto higher malaria vector abundance ActaTropica 105 (2008) 67-73

[19] Adewuyi S.A., Philip B.B., Ayinde I.A. and Akerele D. (2010) Analysis of Profitability of Fish Farming in Ogun State, Nigeria

[20] Okechi, J.K. and Jensson, P. (2004) Profitability Assessment:
A case study of African Catfish farming in the Lake Victoria Basin, Kenya. University of Iceland, Reykjavik.

[21] Maina, J.G., Mbuthia, P.G, Ngugi, C, Omolo, B, Orina, P; Wangia, S.W, Karuri, E,G, Maitho, T, Owiti, G.O,(2014) Influence of social-economic factors, gender and the Fish Farming Enterprise and Productivity Project on fish farming practices in Kenya. Livestock Research for Rural Development 26 (2) 2014.

[22] Olowosegun T., Sanni A. O., Sule A. M. and Bwala R. L. (2004) Contribution of Women to Fisheries development in Kainji Lake Basin, in 2004 FISON Conference proceedings, Pp 91-97.

[23] Olaoye O. J., Ashley-Dejo S. S., Fakoya E. O., Ikeweinwe N. B., Ashaolu F.O. \& Adelaja O. A.(2013) Assessment of Socio-Economic Analysis of Fish Farming in Oyo State, Nigeria

[24] Osondu C. K. and Ijioma, J. C. (2014)Analysis of profitability and production determinants of fish farming in Umuahia Capital Territory of Abia State, Nigeria World Journal of Agricultural Sciences Vol. 2 (7), pp. 168-176.

[25] FAO (2013) Aquaculture production: Frame survey in Western Kenya. Food and Agriculture Organization of the United Nations, Rome, Italy.

[26] Njagi,A. K., Ibuathu, C. N. and GuyoHuka S. (2013) Factors Affecting Profitability of Fish Farming Under Economic Stimulus Programme in Tigania East District, Meru County, Kenya. IOSR Journal of Business and Management Volume 15, Issue 3 (Nov. - Dec. 2013), PP 25-36

[27] Asmah, R. (2008). Development of Potential and financial viability of fish farming in Ghana. Unpublished $\mathrm{PhD}$ Thesis University of Stirling UK.

[28] Mutambuki, M. K. and Orwa, B. H. (2014) Marketing Strategies of Commercial Fish Farming under Economic Stimulus Programme (ESP) in Kenya: An Empirical Study of Kitui County. International Journal of Humanities and Social Science 4. 8(1).

[29] Maina, J.G. (2012) Factors influencing fish production in Mwea division in Kirinyaga County, Kenya. Unpublished Msc. Thesis University of Nairobi.

[30] Ronnback, P; Bryceson, I and Kautsky, N.(2002) Coastal Aquaculture Development in prospects and problems for food security and Local Economies. Royal Swedish Academy of Science 31: 7-8 2002

[31] Ataga, R (2015) Unpublished report, Makueni County Fishery Department, Wote, Kenya 